\title{
35. GEOLOGY OF THE ARUBA GAP ABYSSAL PLAIN NEAR DSDP SITE 153
}

\author{
H. R. Hopkins, Esso Production Research Co., Houston, Texas
}

\begin{abstract}
SUMMARY
The drilling of DSDP Site 153 adjacent to two processed seismic lines provided an opportunity to describe the geology of the area. Correlation between the drilling and seismic data proved to be excellent. Interpretation of these data result in the following conclusions: there are sediments below the oldest rocks drilled; strike-slip faulting is widespread and is the dominant structural style in the area; the faulting has progressively migrated northward; there has been continued relative movement between the Beata Ridge and the abyssal plain since Late Cretaceous time; and the Caribbean plate may be divided into two subplates in the area surveyed.
\end{abstract}

\section{INTRODUCTION}

During November, 1969, two deep-penetrating CDP (Common Depth Point) seismic lines were run across the Aruba Gap Abyssal Plain in the southwestern Caribbean (Figure 1). A portion of one of these lines (B-2) was made available to JOIDES to assist in locating Site 153. The lines were recorded to a maximum depth of $14 \mathrm{sec}$, but no interpretable coherent primary reflections occurred below 9 sec. The energy source was 8 EPRC gas sleeve exploders, and the data were digitally recorded on magnetic tape. A short hydrophone streamer was used to record highfrequency data and monitored on shipboard to produce a real time single-fold record. The balance of the seismic data was processed to produce the accompanying twelve-fold CDP seismic records.

Magnetic data were collected during the survey using a 5 -sec sample rate with an accuracy of 1 gamma. Variations in the magnetic field were monitored by a continuously recording magnetic base station on shore.

The omega radio system was used for survey positioning. Radio signals were monitored every 15 minutes, and preliminary plots, using projected corrections, were made on board ship. Final position plots were calculated later using actual correction factors. The positioning is estimated to be accurate to within 3000 feet.

The author wishes to thank Esso Production Research Company for its permission to publish the seismic data and the many people who have taken time to discuss the geology of the Caribbean with the author. The illustrations were drafted by Caroline Peacock and Travis Conboy, whose skill and patience are greatly appreciated.

\section{DRILL HOLE-SEISMIC CORRELATION}

DSDP Site 153 was drilled approximately 4800 meters east of seismic line B-2 and has afforded an excellent opportunity to use the invaluable DSDP data to unravel geologic history in this area. The drill hole data were projected westerly (WSW), intersecting the seismic line at shotpoint 47 . This point is the closest approach of the seismic line to the drill site; it is at the same water depth (3932 $\mathrm{m})$, using the calculated water velocity determined in the area, and is in approximately the same structural position as described by N.T. Edgar (personal communication, 1972).

Figure 2 shows the core and important geologic tops (A through J) encountered in DSDP Site 153 relative to the single-fold and twelve-fold seismic lines. The positions of these tops were determined by calculating the reflection velocities from the CDP data and multiplying this value by the recorded drill depths. A summary of the tops, ages, depths, and two-way seismic time is given in Table 1 .

Before the drill hole data were projected into the seismic line, the seismic data were interpreted. Nine recognizable seismic horizons were mapped [Horizons 1 through 8 of Figure 2 and Table 1, plus oceanic (?) crust, horizon]. Horizon 1 is locally a very strong reflector which occurs above the middle Pliocene (Core A) and probably represents the top of the Pliocene. Horizon 2 corresponds with core interval $\mathrm{B}$ and is middle Pliocene in age. Horizon 3 occurs above core interval $\mathrm{C}$, of middle Miocene age, and probably represents the top of the early Pliocene. Horizon 4 is interpreted as a horizon within the late Miocene. Seismic Horizon 5 coincides with middle Miocene Core C. This horizon is a strong reflector in the Aruba Gap area and represents a good seismic horizon which should be traceable over most of the Caribbean. Seismic Horizon 6 occurs between the early Miocene and middle Oligocene cored intervals (Cores D and E) and is considered to be at or near the top of the Oligocene. Horizon 7 is marked by a conspicuous unconformity in the vicinity of DSDP Site 153 and represents the Tertiary-Cretaceous (Maastrichtian) unconformity cored in interval G. Seismic Horizon 8 occurs at or near the position of the probable Coniacian basalt cored in interval $\mathbf{J}$ to the total depth of the drill hole. This interval is marked by a very high amplitude event occurring in the area around the drill hole. 


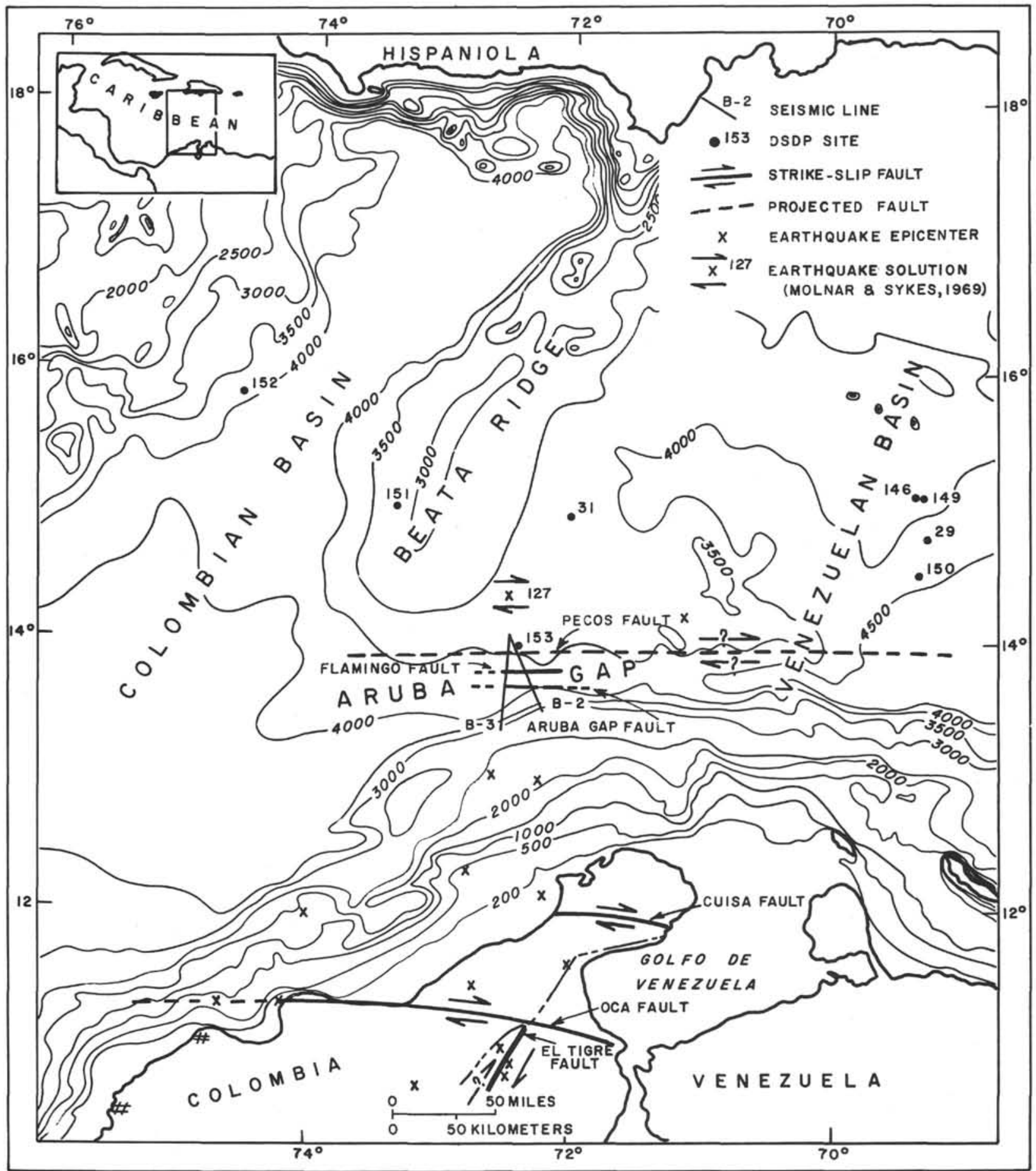

Figure 1. Western Caribbean area showing location of seismic lines B-2 and B-3 and major faults. Bathymetry in meters from Tectonic Map of North America (1969). Earthquake epicenters from NOAA 1961-1972 (for the area longitude $71^{\circ}$ to $75^{\circ} \mathrm{W}$, latitude $11^{\circ}$ to $15^{\circ} \mathrm{N}$ only). Onshore fault trends from Alvarez (1967), Miller (1962), Raasveldet (1956), Rod (1956), and Tschanz et al. (1969). 
Site 153

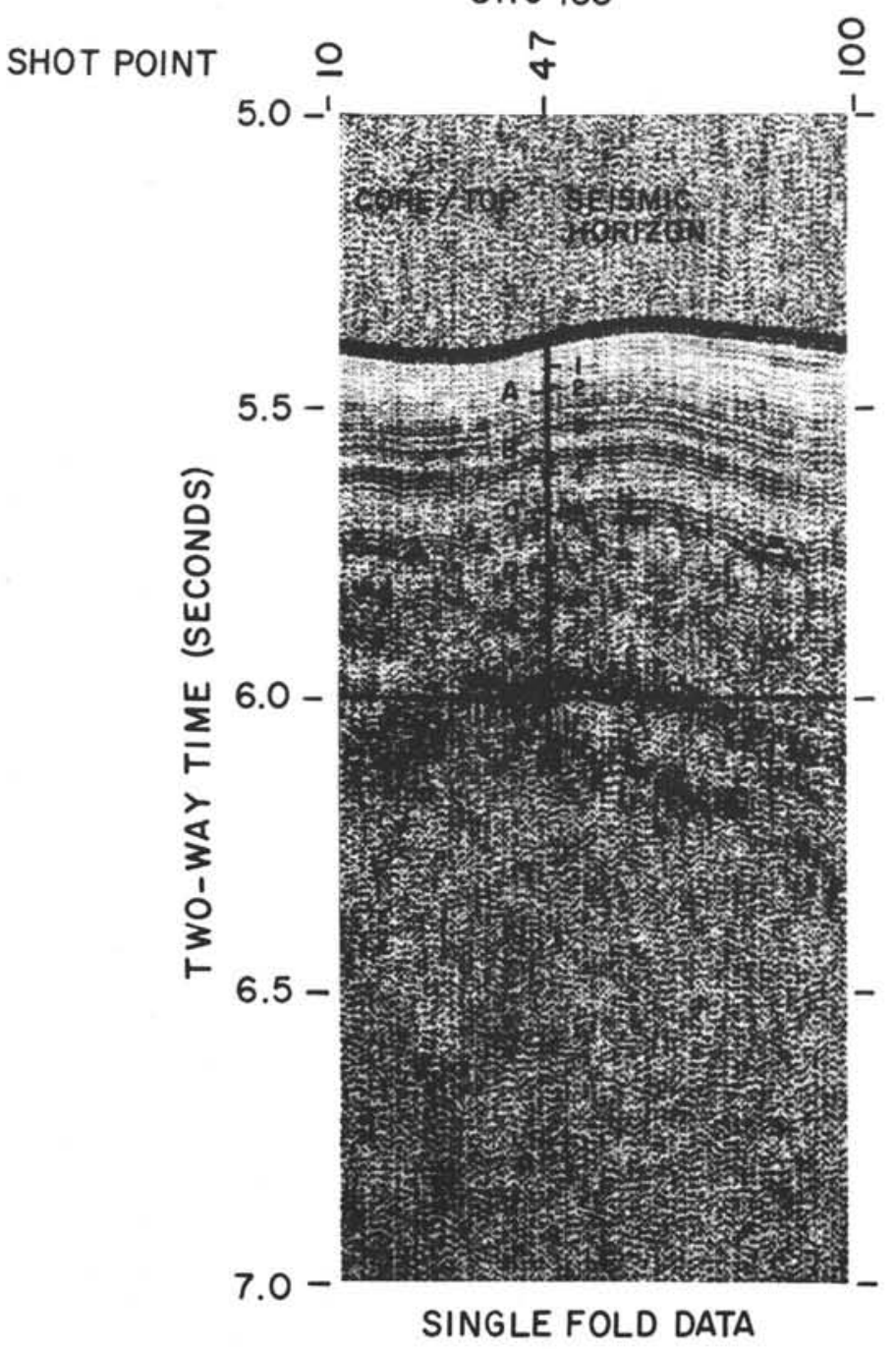

(a)
Site 153
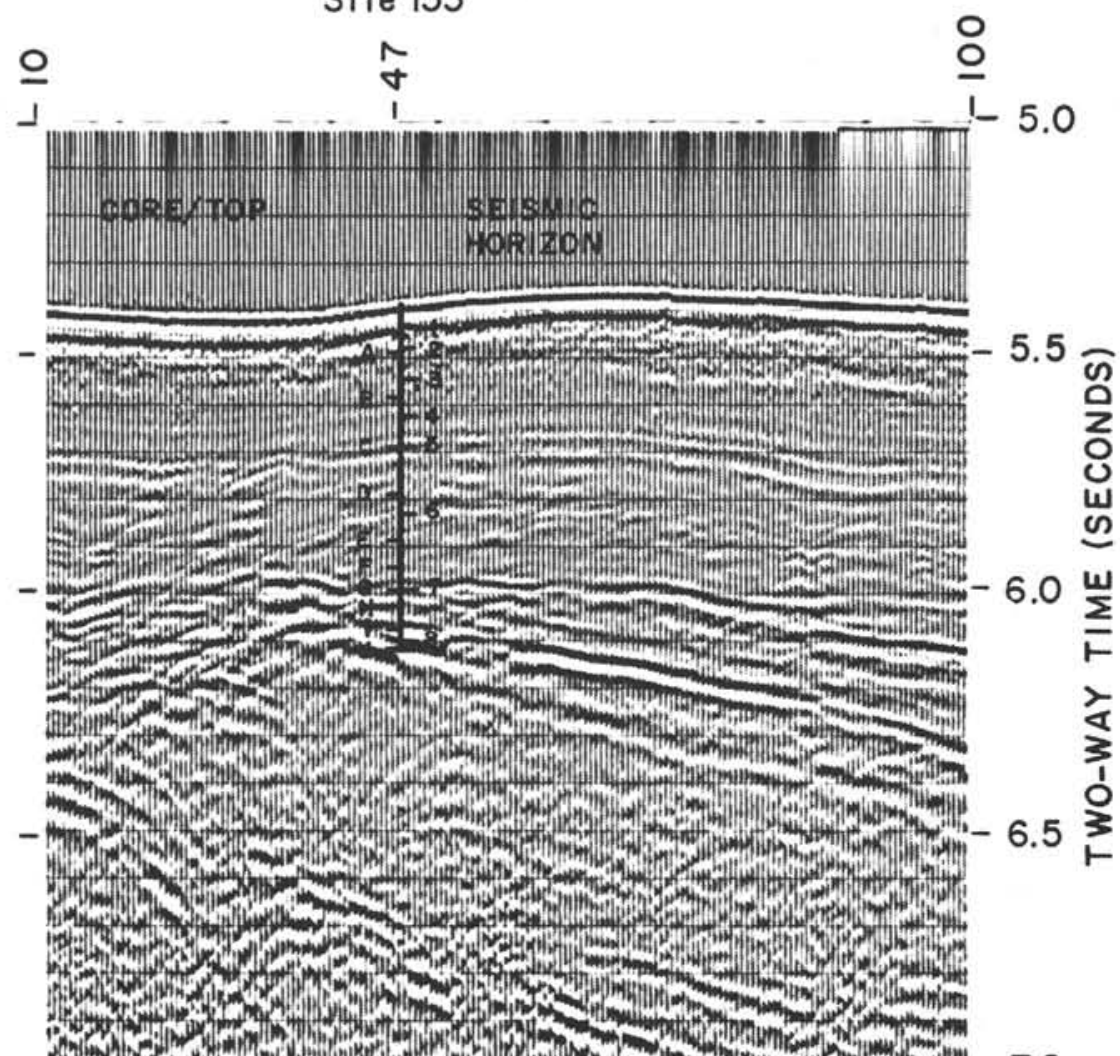

- $y_{0}$.

TWELVE FOLD PROCESSED DATA

(b)

Figure 2. Correlation of core depths and geologic units at DSDP Site 153. (a) Single-fold data, and (b) twelve-fold processed data of the same area. A through $J$ are tops of core intervals or geologic contacts; 1 through 8 are mapped seismic horizons (see Table 1). (Horizontal distance is approximately $10 \mathrm{~km}$. 
TABLE 1

Correlation of Drill Hole Depths and Calculated Seismic Times with Seismic Horizon Times and Calculated Depths

\begin{tabular}{|c|c|c|c|c|c|c|}
\hline \multicolumn{4}{|c|}{ Drill Hole } & \multicolumn{3}{|c|}{ Seismic Line } \\
\hline Core/Tops & $\mathrm{Age}^{\mathrm{a}}$ & $\begin{array}{c}\text { Depth } \\
\text { (m) }\end{array}$ & $\begin{array}{c}\text { Two-way b } \\
\text { Seismic } \\
\text { Time } \\
\text { (sec) }\end{array}$ & Horizon & $\begin{array}{l}\text { Depth }{ }^{\mathrm{b}} \\
\text { (m) }\end{array}$ & $\begin{array}{c}\text { Two-way } \\
\text { Time } \\
\text { (sec) }\end{array}$ \\
\hline Water Bottom & & 3932 & 5.37 & $\begin{array}{c}\text { Water Bottom } \\
1\end{array}$ & $\begin{array}{l}3932 \\
3982\end{array}$ & $\begin{array}{l}5.37 \\
5.42\end{array}$ \\
\hline A & M. Pliocene & 4034 & 5.47 & $\begin{array}{l}2 \\
3\end{array}$ & $\begin{array}{r}4022 \\
.4093\end{array}$ & $\begin{array}{l}5.46 \\
5.53\end{array}$ \\
\hline B & L. Miocene & 4132 & 5.57 & 4 & 4173 & 5.61 \\
\hline $\begin{array}{l}\text { C } \\
\text { D }\end{array}$ & $\begin{array}{l}\text { M. Miocene } \\
\text { E. Miocene }\end{array}$ & $\begin{array}{l}4232 \\
4335\end{array}$ & $\begin{array}{l}5.67 \\
5.77\end{array}$ & 5 & 4243 & 5.68 \\
\hline E & M. Oligocene & 4432 & 5.87 & 6 & 4384 & 5.82 \\
\hline F & E. Eocene & 4495 & 5.93 & & & \\
\hline $\begin{array}{l}\mathrm{G} \\
\mathrm{H}\end{array}$ & $\begin{array}{l}\text { Maestrichtian } \\
\text { Santonian }\end{array}$ & $\begin{array}{l}4541 \\
4663\end{array}$ & $\begin{array}{l}5.98 \\
6.06\end{array}$ & 7 & 4541 & 5.98 \\
\hline $\begin{array}{c}\text { J } \\
\text { T.D. }\end{array}$ & Basalt & $\begin{array}{l}4691 \\
4708\end{array}$ & $\begin{array}{l}6.09 \\
6.10\end{array}$ & 8 & 4684 & 6.09 \\
\hline
\end{tabular}

${ }^{\mathrm{a}} \mathrm{E}$-early, M-middle, $\mathrm{L}$-late.

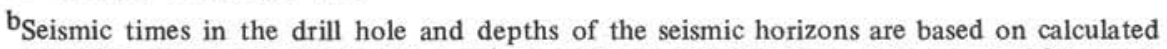
velocities. Water velocity is $1,4 \cup 3 \mathrm{~m} / \mathrm{sec}$; sediment velocity from $5.37 \mathrm{sec}$ to $5.98 \mathrm{sec}$ is $2,009 \mathrm{~m} / \mathrm{sec}$; and rock velocity below $5.98 \mathrm{sec}$ is $2,528 \mathrm{~m} / \mathrm{sec}$.

The coincidence of the middle Miocene with a strong regional seismic reflector and of the basalt with a strong, high-amplitude reflector indicates a high degree of correlation between DSDP Site 153 data and seismic line B-2.

\section{INTERPRETATION OF SURVEY DATA}

The primary interpretation was made on the twelve-fold CDP data (Figure 3), and the horizons were correlated with the single-fold data (Figure 4) in the shallower part of the section. In difficult areas, over the strucutral highs and in areas of defractions, the horizons were carried on the single-fold data and recorrelated with the CDP data. The resulting interpretations presented in Figures $3 \mathrm{a}$ and $3 \mathrm{c}$ are a composite of the interpretations from the single-fold and seismic data.

To facilitate reference to the sections, the major structural features, the fault zones, and associated highs have been here named the Aruba Gap fault zone, after the location, and the Pecos and Flamingo fault zones, after the seismic ship R.V. Pecos and support ship M.V. Flamingo (Figures 1,3).

The base of the predominantly sedimentary section (Horizon 9), not penetrated at Site 153, is considered to be possible oceanic crust. The reflection is characterized by two or three strong, high-amplitude events and is the deepest, continuous, coherent reflection observed on the original 14-sec records. The interval velocities from reflection data, however, are low for normal oceanic crust, ranging from 4.8 to $5.3 \mathrm{~km} / \mathrm{sec}$, and may indicate an intermediate composition. Several velocity calculations at or above Horizon 9, such as the one at shotpoint 80 on line B-2 (Figure 3a), have velocities in the basalt range, which implies that local basalt flows occur above Horizon 9 throughout the area.

There is no direct evidence to indicate the age of the basement (or crust) in the western Caribbean. It must, however, be older than Coniacian, the oldest rocks drilled. The seismic data suggests that a thick volcanic-sedimentary section lies below the oldest dated rock in the Aruba Gap area. The best estimate is that the basement is probably Early Cretaceous or Jurassic in age. A more precise dating will have to be deferred until more information is available.

The top of Cretaceous Coniacian or basalt flow of Site 153 coincides with Horizon 8 and is marked by one or several continuous seismic reflections. The reflection velocities on line B-2 (Figure 3a) range from 3.7 to 3.9 $\mathrm{km} / \mathrm{sec}$, precluding the possibility that this unit is composed dominantly of basalt, although the occasional high velocities mentioned above occur in this unit, and sporadic, restricted, high-amplitude reflections are present. These data would indicate that the section between Horizons 8 and 9 is composed of sediment with interbedded basalt, especially along line B-2. On line B-3 (Figure 3c) there are a series of wavy discontinuous high-amplitude reflections which may represent basalt flows; however, the apparent reflection velocity is very slow, indicating probable compacted sediment.

Horizon 7 is a conspicuous unconformity and represents the top of the Maastrichtian. North of the Pecos fault zone on line B-2 (Figure 3a) beds in a small syncline are tilted and truncated. These rocks in the syncline next to the fault zone have reflection velocities of about $6.9 \mathrm{~km} / \mathrm{sec}$ and probably are a thick series of basalt flows associated with the faulting. 
N

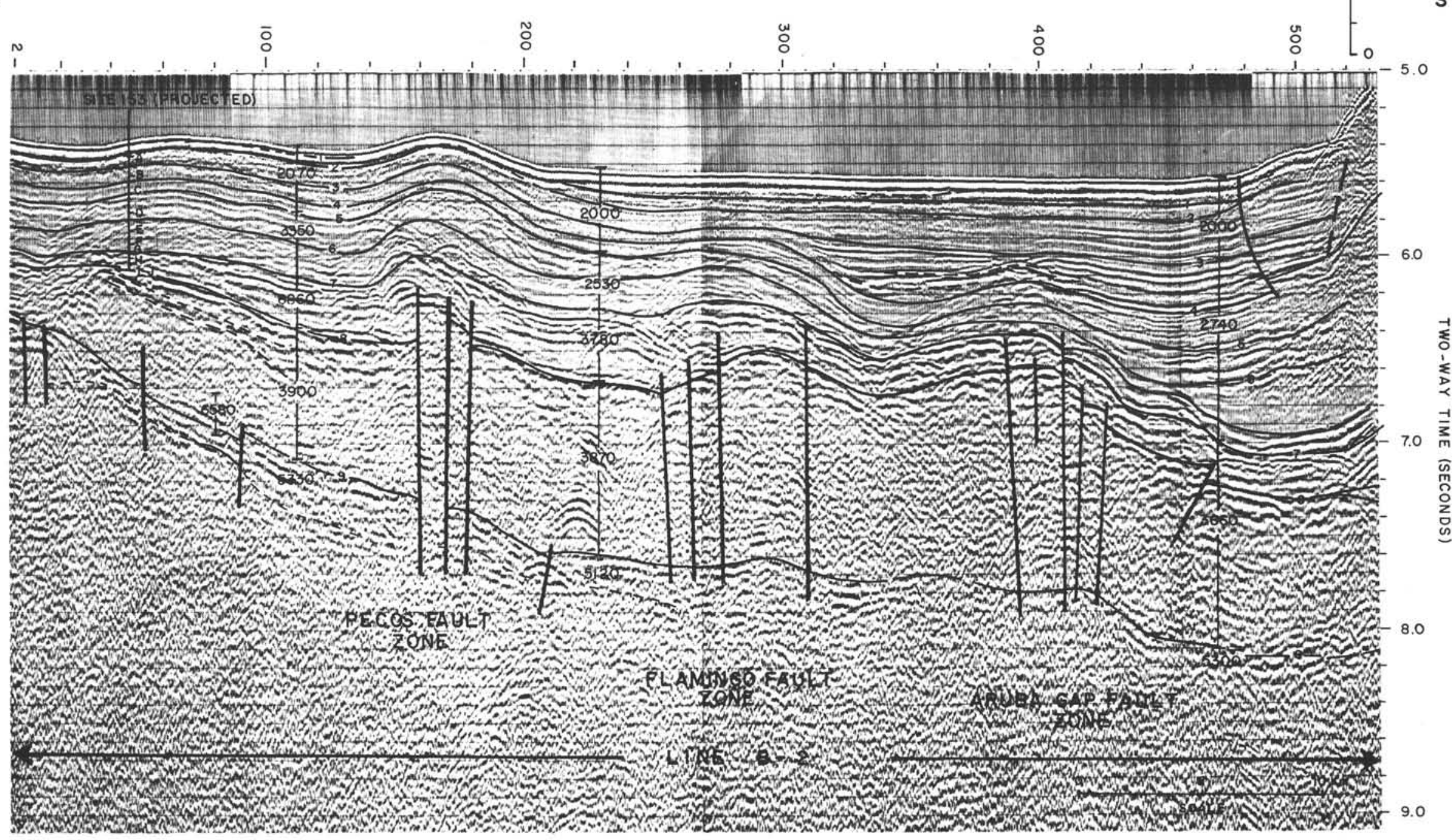

列 in $\mathrm{m} / \mathrm{sec}$. Vertical exaggeration is approximately 10:1. 


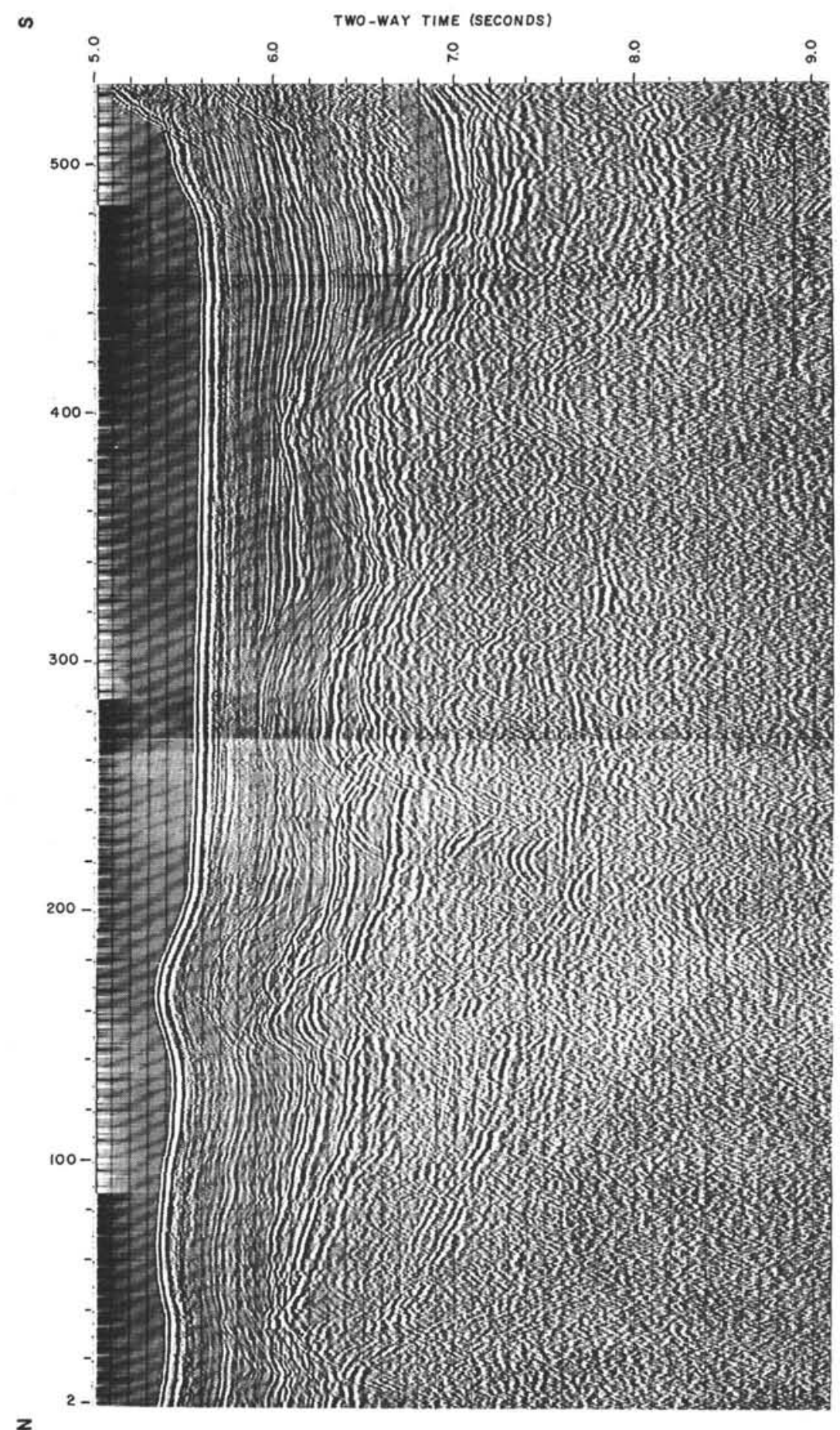

Figure 3b. Uninterpreted CDP line B-2.

The relative magnetic intensity profiles shown across the top of Figures $3 \mathrm{a}$ and $3 \mathrm{c}$ show no significant anomalies which can be used to determine the depth to magnetic basement. The smaller anomalies are apparently noise and result in too shallow a depth. The larger anomalies are poorely defined or result in extremely deep estimates of magnetic basement.

The balance of the stratigraphic section is composed of silicified limestone, chalk, and some marl with varying amounts of clay deposited in a subsiding deep-water basin. 


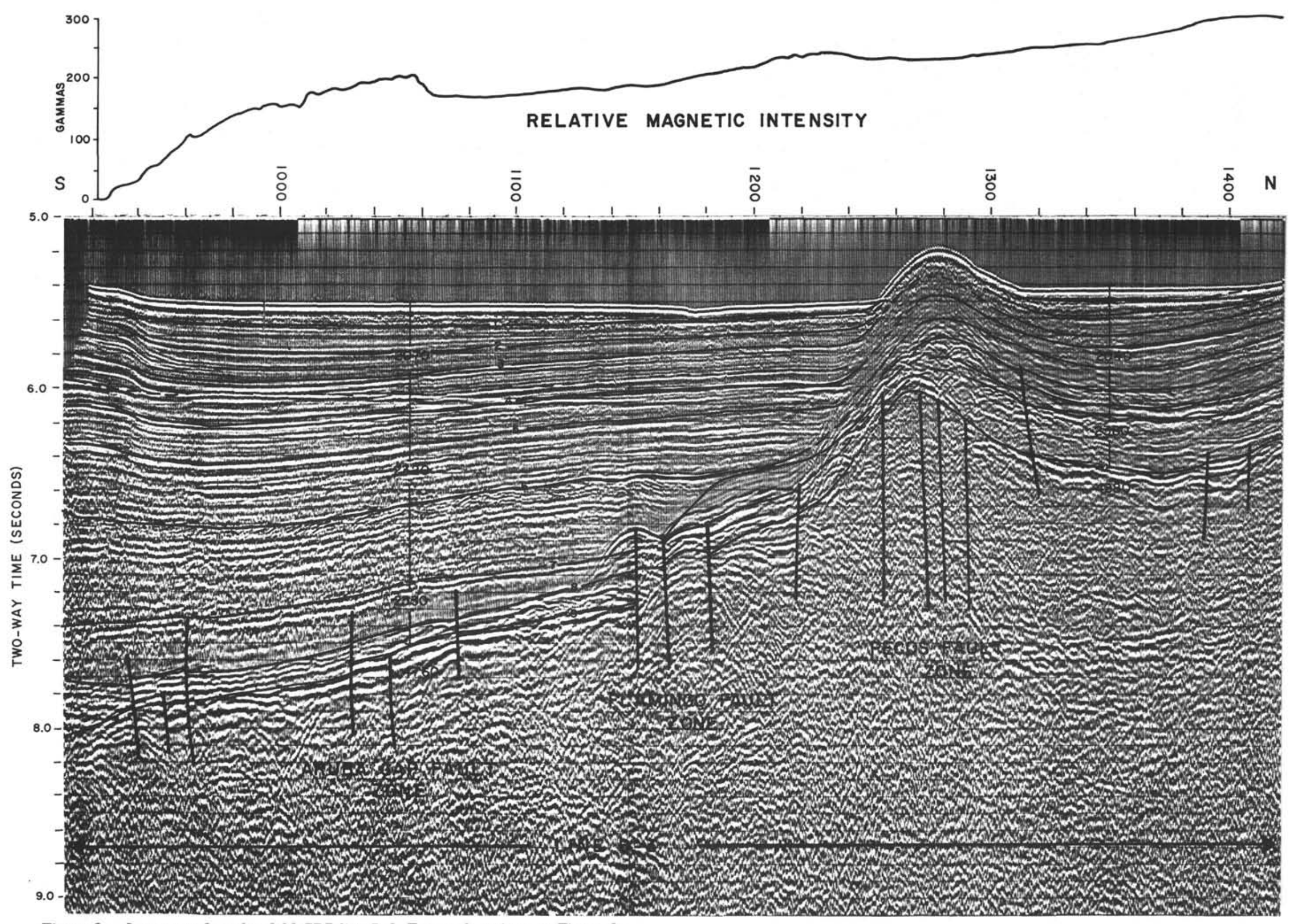

Figure 3c. Interpreted twelve-fold CDP line B-3. For explanation see Figure 3a. 


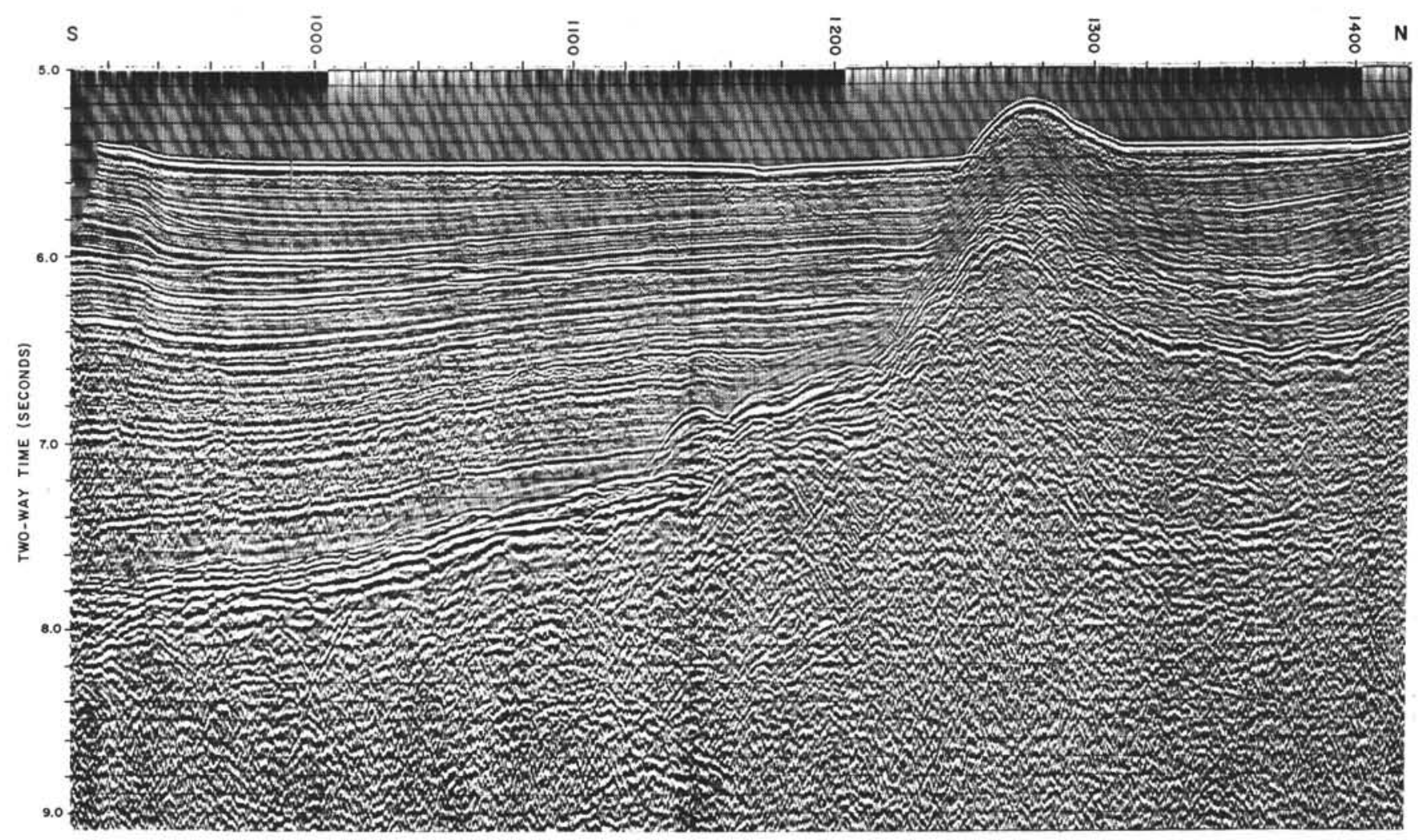

Figure 3d. Uninterpreted CDP line B-3.

\section{STRUCTURAL GEOLOGY}

Seismic lines B-2 and B-3 (Figure 3) trend northwest and northeast, respectively (Figure 1), intersecting at about latitude $14^{\circ} \mathrm{N}$, and cross the entire width of the narrow $(28-33 \mathrm{~km})$ Aruba Gap Abyssal Plain, which connects the Colombian Basin on the west with the Venezuelan Basin on the east. The southern ends of the lines begin at the foot of the South American continental rise and proceed northward across the Aruba Gap Abyssal Plain, which has a water depth of between 4020 and 4080 meters. At shotpoints 170 (Figure 3a) and 1280 (Figure 3c), associated with the Pecos fault zone, the lines cross a structural high with a maximum relief of 240 meters. This high marks the southern edge of the Beata Ridge rise, and the water depth north of the high is about 100 meters less than depths of the abyssal plain.

The juncture of the South American rise and the abyssal plain (shotpoint 520, Figure 3a; shotpoint 940, Figure 3c) is marked by a thrust fault or pronounced monocline in the mid-Miocene and younger sediments, indicating either minor northward-directed tectonic forces or more probably a gliding or flowage of a high-standing unstable clay-prone section into the abyssal plain.

The major structural features of the area are the prominent structural highs and buried scarps associated with faulting. These faults are interpreted as east-west trending, right-lateral, strike-slip faults based on the following evidence. The southern edge of the Beata Ridge is a slightly undulating east-west, low-relief ridge or slope break nearly $400 \mathrm{~km}$ long, and the most prominent faulted high, the Pecos fault zone, coincides with the slope break along the seismic lines. Recent high-power sparker data acquired by the U.S. Geological Survey (Silver, 1972) indicate that the same type of deep structural features are present eastward along the 14 th parallel at least to longitude $69^{\circ} \mathrm{W}$. This amounts to a minimum east-west linear bathymetric and fault trend about $500 \mathrm{~km}$ long. Linear fault trends are characteristic of strike-slip or transform faulting.

The primary structural style along the northern coast of Colombia and Venezuela is right-lateral strike-slip faulting (Alvarez, 1967), Bucher, 1952, Miller, 1962, Raasveldet, 1956; Rod, 1956; Tschanz et al., 1969). Two of these faults, the Cuisa and Oca, trend east-west, as do others in eastern and central Venezuela, establishing a general eastwest strike-slip margin for the northern border of the south American continent.

Molnar and Sykes (1969) published first-motion studies on some Caribbean earthquakes, one of which occurred about $40 \mathrm{~km}$ north of the survey area (Figure 1). The hypocenter was $33 \mathrm{~km}$ (NOAA), and an analysis of the seismograms indicated a vertical fault plane trending eastwest with right-lateral movement (Molnar and Sykes, 1969, p. 1661, solution 127). Eight of fourteen earthquakes occurring in the survey area since 1960 are associated with documented or probable strike-slip faults. The presence of earthquakes in the Caribbean, the association of many of these earthquakes with strike-slip faulting, and the firstmotion study by Molnar and Sykes establish the presence of strike-slip faulting in the western Caribbean as far north 
as latitude $14.40^{\circ} \mathrm{N}$. The lack of direct evidence for strike-slip faulting beyond this latitude tends to establish this as the northern limit of east-west wrenching in the Beata Ridge area.

The proximity and areal relationship of the vertical to steeply dipping faults along the southern portion of line B-3 indicate that these also must be strike-slip faults, although there is no direct evidence for this conclusion. First, all these faults are close to vertical and plot nearly due west of the strike-slip faults on line B-2, and we have already established the east-west trend of the major faulting. Second, both sets of faults are interpreted as offsetting the same stratigraphic section which clearly implies a chronologic relationship. In addition, both normal and reverse fault motion occurs along the faults, with some apparent overthrusting. Harding (1973) and Wilcox et al. (1973) illustrate the above relationships and document the changes from apparent normal faulting to apparent reverse faulting and the associated overthrusting along a single-strike-slip fault.

\section{GEOLOGIC DEVELOPMENT}

A general sedimentary history of the Aruba Gap area can now be developed on the basis of the correlations and ages assigned to the seismic horizons.

Basement (Horizon 9) must have been a slightly tilted plane or surface dipping to the southwest, indicating formation of an incipient Beata Ridge-Venezuelan Basin just prior to deposition of the pre-Coniacian rocks. The Coniacian and pre-Coniacian sediments, with associated volcanics (Horizons 9 to 8 ), were deposited on the tilted basement surface. An extremely thick section accumulated in the eastern area long line B-2 (Figure 3a), while the corresponding section in the area of line B-3 (Figure 3C) was much thinner. The disparity in thickness is probably related to subsidence of the Venezuelan Basin and proximity to the South American land mass.

During the Santonian and Maastrichtian (Horizons 8 to 7) the Beata Ridge continued to rise and/or the Aruba Gap Abyssal Plain subsided as shown by lapping of the Coniacian surface by the younger Cretaceous rocks. By the end of the Maastrichtian, the southern end of the Beata Ridge was subjected to erosion, and initial strike-slip faulting occurred along the Aruba Gap and Flamingo faults.

The Tertiary rocks successively onlap and thin over the Beata Ridge high and thicken in the abyssal plain. The movement along the strike-slip faults migrated progressively northward as indicated by successive onlap against the fault-controlled highs (Figure 3a).

The Aruba Gap fault zone began to move during the Late Cretaceous and continued to move into late Miocene time. Movement had completely ceased by the middle Pliocene. In the late Miocene, most of the fault movement had shifted northward to the Flamingo fault zone, which had significant movement until middle Pliocene time, when it became inactive. The movement again shifted northward to the Pecos fault, which began to move during the late Miocene and is probably moving today as evidenced by its topographic expression on the sea floor and the onlapping of the youngest detectable sediments (Figure $4 \mathrm{a}, 4 \mathrm{~b}$ ) against the flanks of the high.

\section{REGIONAL SIGNIFICANCE OF FAULTING}

Two regional observations can be made concerning the faulting in the area: (1) crustal movements have taken and are taking place in the Aruba Gap area; and (2) the movement has varied with time.

Right-lateral strike-slip movement occurs along the northern edge of the Sourth American continent and is present in the Caribbean as far northward as latitude $14.40^{\circ} \mathrm{N}$. The southernmost set of faults (Oca, San Sebastian, and El Pilar) is presently moving as shown by recent earthquake activity (Molnar and Sykes, 1969; Figure 1). The northernmost set of faults are presently active as evidenced by earthquake activity (Molnar and Sykes, 1969; solution 127) or have moved, at least since the Pliocene, the Pecos fault zone, which has folded Pliocene and possibly younger sediments (Figure 3 ). The sourthern set marks the accepted boundary of the South American and Caribbean plates. The northern set ocurs within the Caribbean plate and is considered to be subplate boundary which, at least for the western Caribbean, divides the Caribbean plate into a northern Caribbean subplate and a sourthern Caribbean subplate. Figure 3 shows that these strike-slip faults affect the upper part of the Caribbean crust, and NOAA (1961-1972) reports that the earthquake at solution 127 of Molnar and Sykes (1969) had a focus depth of $33 \mathrm{~km}$ or less, within the upper mantle or crust based on the calculated top of mantle $(17$ and $24 \mathrm{~km})$ at refraction station 81 reported by Edgar et al. (1971).

On the basis of the stratigraphic relationships, it is obvious that movement along the strike-slip faults in the Aruba Gap have varied with time. The southernmost fault zone (Figure 3), Aruba Gap fault zone, was active during the Pliocene and probably Pleistocene and may have minor activity today.

The northern migration of the active fault zone substantiates the implication of Molnar and Sykes (1969) that the stress in the western Caribbean is directed to the ENE (Figure 5), and because of the blocking effect of the South American continent against the wedge-shaped Caribbean plate, the ENE stress is translated into an easterly plate motion.

In detail, the data suggest the following regional tectonic development. The Caribbean plate approximates a deformed, eastward-pointing right triangle or wedge with a gently curved northern boundary. This small plate occurs between two massive plates, the northern and southern American plates. Relative movement on the wedge base, or western edge of the Caribbean plate, is directed to the northeast. However, movement to the north is restricted by the northern American plate and is translated into east-west strike-slip movement along the Cayman Trough fault and associated fault zones. Movement to the south is restricted by the southern American plate and is also translated into east-west strike-slip movement on multiple fault zones along the South American coast. Thus the northeastward movement at the base is channeled into an eastward movement at the apex of the wedge.

From the wedge base, along the Central American isthmus, to the Aruba Gap area, the Caribbean plate wedge narrows from approximately $2100 \mathrm{~km}$ to $1050 \mathrm{~km}$. This change in width creates a space problem as the Caribbean 
SHOT POINT

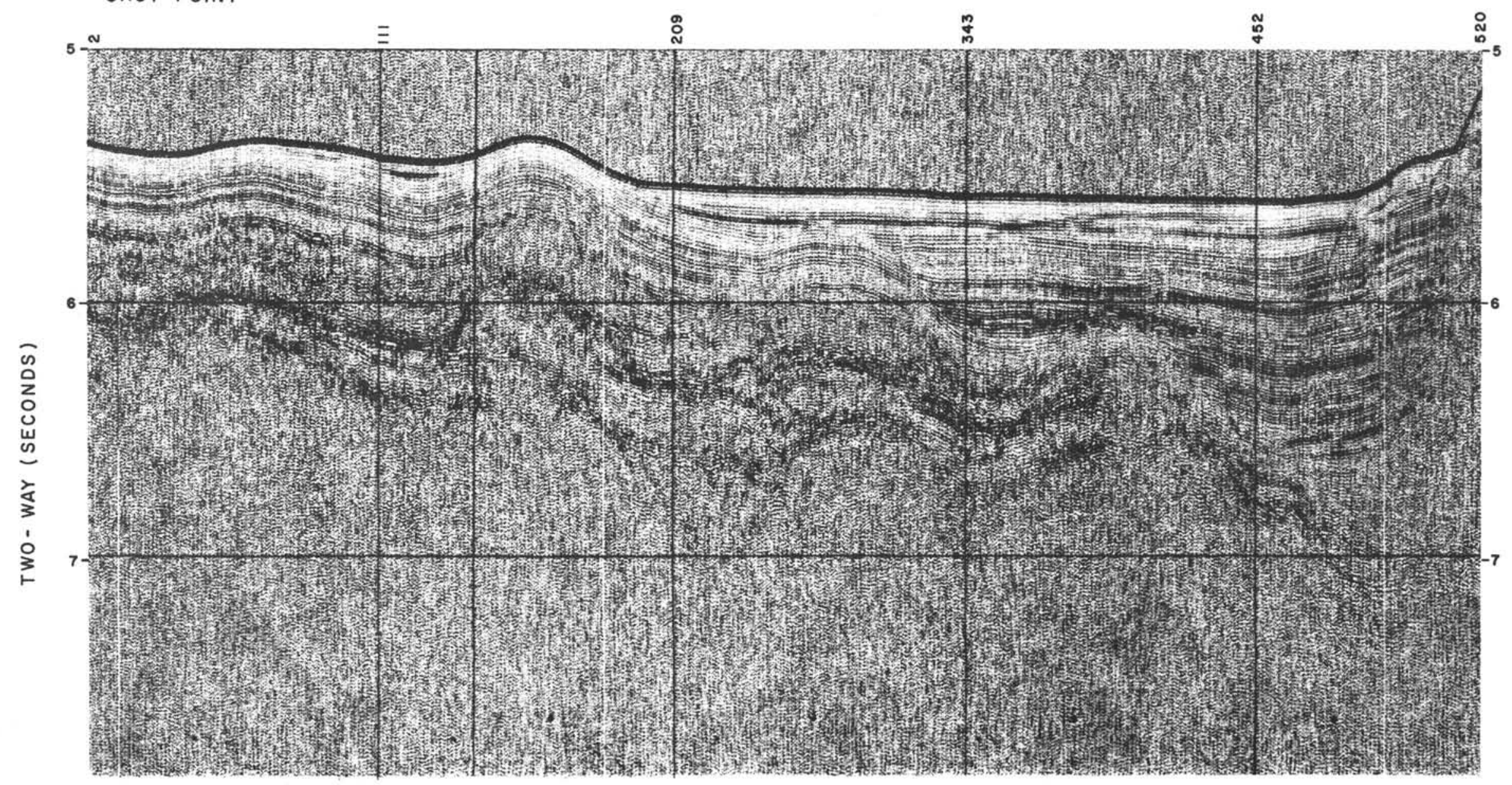

Figure 4a. Single-fold seismic line B-2. 


\section{SHOT POINT}

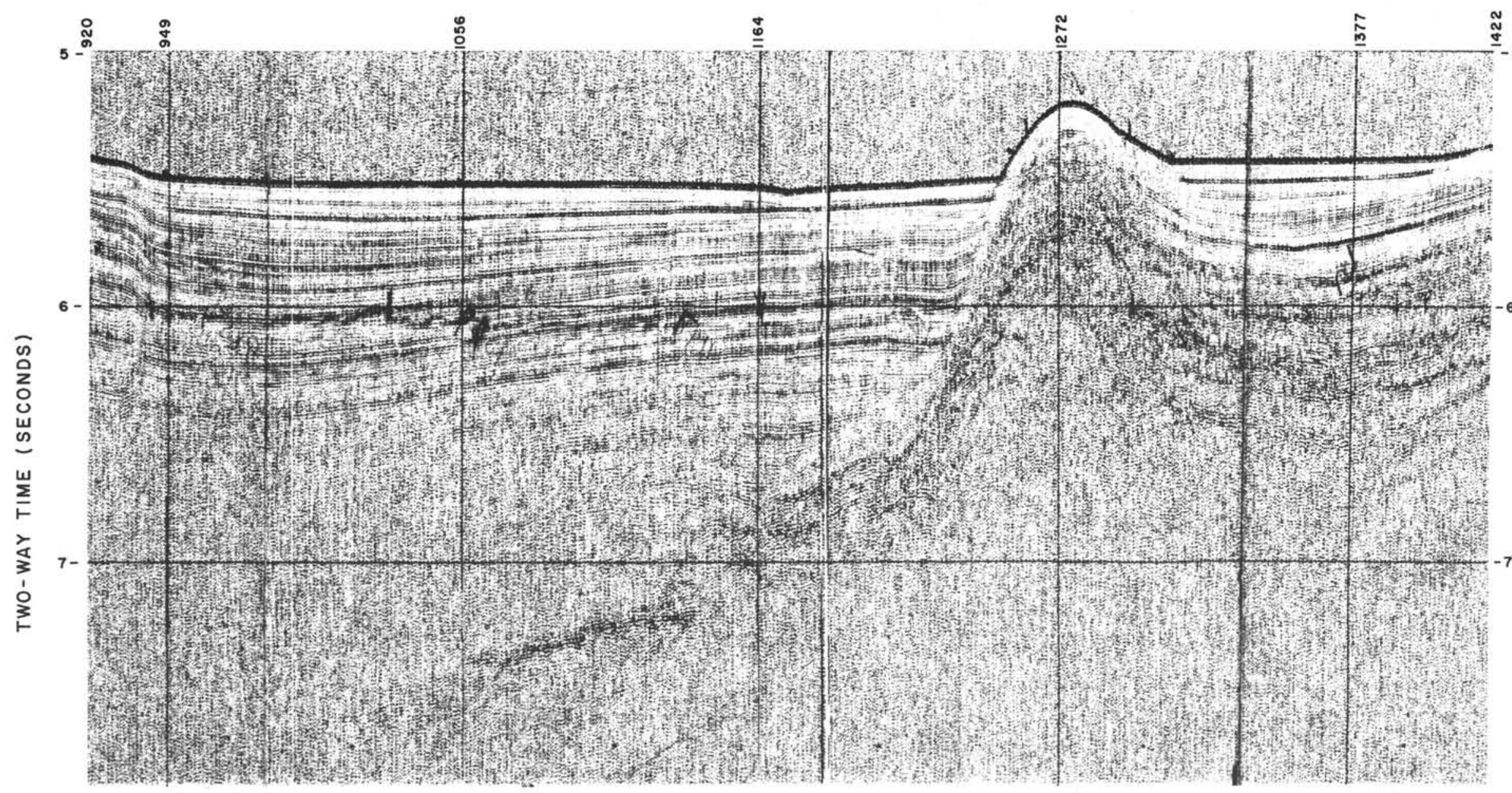

Figure 4b. Single-fold seismic line B-3. 


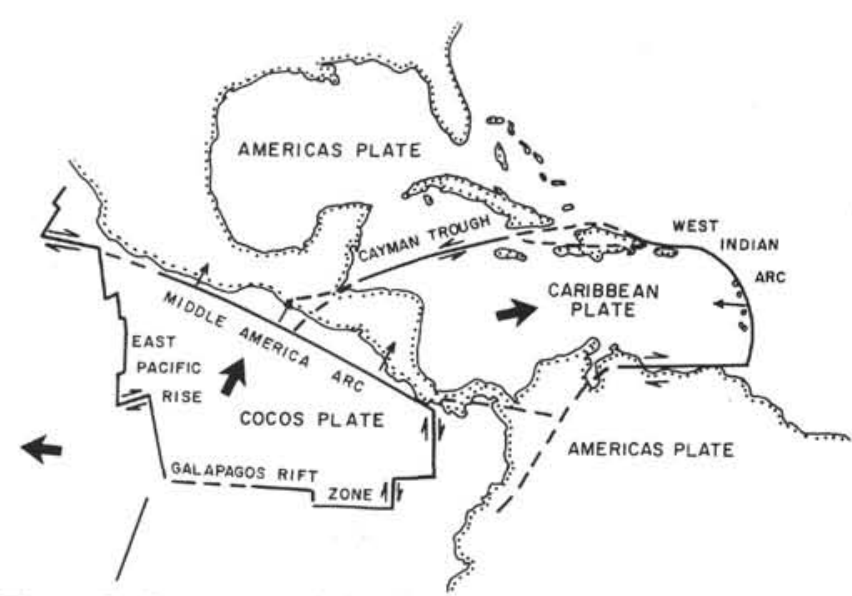

Figure 5. Location of Caribbean plate boundaries. Heavy lines designate plate boundaries, small arrows indicate relative movement along transform faults or dip of Benioff zones along trenches, and heavy arrows indicate relative plate motion (from Molnar and Sykes, 1969).

plate moves relatively eastward and results in a series of shears (strike-slip faults) which are parallel or subparallel to the Caribbean-southern American plate boundary. As the Caribbean plate moved eastward, the earliest faults formed where the width of the wedge equaled or was slightly greater than the separation between the American plates. With continued plate movement, the force necessary to sustain movement on the fault increased owing to narrowing of the area between the American plates until the stress was relieved along a younger fault which formed northward of the original fault. This sequence of events continued to the present and has resulted in a series of nearly east-west strike-slip faults which overlap each other in time, but become progressively younger to the north.

\section{REFERENCES}

Alvarez, W., 1967. Geology of Simarua and Corpintero areas, Guajira Peninsula, Colombia. Ph.D. Thesis, Princeton Univ. 168 p.

Bucher, W.H., 1952. Geologic structure and orogenic history of Venezuela. Geol. Soc. Am. Mem. 49. 113 p.

Edgar, N.T., Ewing, J.I. and Hennion, John, 1971. Seismic refraction and reflection in Caribbean Sea. Bull. Am. Assoc. Petrol. Geologists. 55, 833.

Edgar, N.T. et al., 1971. Deep sea drilling project, leg 15. Geotimes. April. 12.

Harding, T.P., 1973. The Newport-Inglewood trend - An example of the wrenching style of deformation. Bull. Am. Assoc. Petrol. Geologists. 57, 97.

Miller, J.B., 1962. Tectonic trends in Sierra de Perija and adjacent parts of Venezuela and Colombia. Bull. Am. Assoc. Petrol. 46, 1565.

Molnar, P. and Sykes, L.R., 1969. Tectonics of the Caribbean and middle America regions and focal mechanisms and seismicity. Bull. Geol. Soc. Am. 80, 1639.

National Oceanic and Atmospheric Administration (NOAA), 1961-1972. U.S. Dept. of Commerce, Earthquake Hypocenter Data, Monthly Repts., Jan. 1961April 1972.

Raasveldet, H.C., 1956. Fallas de Rumbo en el Nordeste de Colombia. Rev. Petroleo. 6, 19.

Rod, E. 1956. Strike-slip faults of northern Venezuela. Bull. Am. Assoc. Petrol. Geologists. 40, 457-476.

Silver, E.A., 1972. Acoustic-reflection profiles, Venezuela continental borderland. U.S. Geol. Surv. Pub. USGSGD-72-005. 23 p.

Tectonic Map of North America, 1968. P.B. King, Compiler. U. S. Geol. Surv.

Tschanz, C.M., Jimeno, A. and Crus, J., 1969. Mapa Geologico de Reconocimiento de la Sierra Nevada de Santa Marta, Colombia. Inst. Nac. Invest. Geol. Min., Ministerio de Minos y Petroleos, Bogota. Map.

Wilcox, R.E., Harding, T.P. and Seely, D.R., 1973, Basic wrench tectonics. Bull. Am. Assoc. Petrol. Geologists. 57,74 . 